\title{
The Polyphonic Onyx: A Study of the Multi-layering of Plurisignification in William Shakespeare's Venus and Adonis
}

\author{
Dr. Aparajita Hazra \\ SKB University, West Bengal, India
}

\begin{abstract}
Shakespeare's Venus and Adonis, unlike the Ovidian original, sets the conventional "man-wooing-woman" context on its head, with the madly lovelorn Venus crazily serenading a very unwilling Adonis, who happens to be a person much younger than her in age as well. My article takes up this seemingly innocuous issue of man turning away from woman in order to probe into a multidimensional discourse of psychoanalysis as well as Queer Theory to try and understand the situation to find out the psychosis that might have been working at the back of Adonis's mind while turning his back petulantly on the importunate Venus. A qualitative analytical approach finds that psychoanalysis would analyze Adonis with the sixth stage of Eriksonian developmental adaptation in humans, while a Lacanian perspective at the issue would rake up suggestions of the "Objet petit a" as the matheme of desire. Again, Queer theorists would stray into fields of discourse on alternate sexuality while hermeneutics would see Adonis's refusal of the normal, natural order of heterosexual love as a subversion of the macrocosmic rubric of the procreative Scala Naturae.
\end{abstract}

Keywords: psychoanalysis, Queer Theory, Objet petit a, hermeneutics, Scala Naturae

\section{Introduction}

Shakespeare's Venus and Adonis is one king-sized 1,196 line-long poem where a severely lovelorn Venus serenades fervently to a grumpy, sulky, irascible, and petulant Adonis only to hear that all he wants to do is hunt boar. The hapless Venus ends up mourning the death of young Adonis who gets gored to death by the very boar he chases. For ages, this poem of Shakespeare's has rather been the Cinderella among all of Shakespeare's immortal works. The young Shakespeare gathered his theme for Venus and Adonis from Ovid's ever-resourceful magnum opus, Metamorphoses. Shakespeare adapted the theme to suit his will. Hence, Ovid's storyline got twisted and turned a bit at certain junctures.

Venus and Adonis has had Shakespeare-lovers marveling at the young, come-hither romance that quietly unfolds in its matrix of over eleven hundred lines. Yet, what strikes one as queer is that one of the parts where Shakespeare wrings the Ovidian plot out of sync is where the lovelorn Adonis of Metamorphoses gets metamorphosed all over again into a frigid, disinterested teenager who never feels roused by the explicit overtures of a very ravishing, very sensual Venus who goes crazily head-over-heels in love with him, thereby even inconveniencing the thematic gravity of the poem a great deal, too. Veering away from the Ovidian original, Shakespeare kneads and moulds the matrix of the poem. A coup de oeill at the lengthy poem reveals a rubric of love that neatly sets the conventional "man-wooing-woman" context on its head, rather making a

Dr. Aparajita Hazra, associate professor, Ph.D., English Department, SKB University. 
queer point with the madly lovelorn Venus crazily serenading a very unwilling Adonis, who happens to be a person much younger than her in age as well. Adonis bucks away from her ardent advances under the pretext that he would rather chase a swine than give in to her embraces.

But there is more to it than meets the eye as the poem with its out-of-the-normal tale of love offers excellent discourse of study in psychoanalysis, Queer Theory, and Ecological Systems Theory.

\section{Cognitive Development Theory}

Psychoanalyst Erik Erikson while promoting the Cognitive Development Theory in psychoanalysis, says that human beings go through eight stages of psycho-social development in life, with each stage punctuated by a specific crisis pertinent to each age (Erikson, 1950). Each stage of psycho-social development posits human being in a singular position that is so fraught with the binaries of opposing characteristics that the subject finds herself or himself locked in a face-off with a conflict of ideologies.

The first stage of infancy in Erik Erikson's theory brings forth the binaries of Trust set against Mistrust with the basic existential question of "Can I really trust the world?" being the main issue with the infant's basic needs being met by the parents thereby leading to trust or mistrust.

The second stage of Erik Erikson's theory centers on the binaries of Autonomy versus Shame and Doubt with the existential question of "Is it OK to be me?" ruling the roost. The parents keep on providing a strong sense of security basing on which the child can make efforts to assert its own will, thereby instilling autonomy in the child.

The third stage posits Initiative vis-a-vis Guilt with the basic existential question being "Is it alright for me to act?" being foremost.

The next stage, the fourth one, brings Competence against Inferiority with the existential question being the "Can I be successful in the real world?" one.

The next stage, the fifth one, shows Fidelity of Identity versus Role Confusion.

The existential question that crops up now is quite vital: "Who am I really and what can I possibly be?".

This stage finds the concerned adolescent engrossed with how they appear to others. Superego identity forms up, followed by a sense of sexual identity. As they make the crossover from childhood to adulthood, adolescents ponder over the roles they will play in the adult world. After some initial hiccups with role confusion, adolescents settle into a sense of identity about who they are.

The next stage is the sixth one-the one where Shakespeare's Adonis would fit in —where the complexity places Love and Intimacy versus Isolation at the threshold of adulthood when the existential question seems to be "Can I love" or "What is love?". Yet at this stage, when Intimacy or Love is supposed to find pride of place, Erikson also argues that "Intimacy has a counterpart: Distantiation: the readiness to isolate and if necessary, to destroy those forces and people whose essence seems dangerous to our own, and whose territory seems to encroach on the extent of one's intimate relations" (Erikson, 1950, p. 52).

The seventh stage finds Generativity versus Stagnation at conflict, as the individual tries hard to "fit in" while the eighth or last stage ponders over Wisdom or Ego Integrity versus Despair through the existential question: "Has it been OK to have been me?".

A diagrammatic representation of the various stages would clarify perspectives up:

A quick look at the diagrammatic representation of the Eight Eriksonian stages of psycho-social development and their congruent crises would make it clear that the first four crises occur during childhood, the 
next one during adolescence and the final three surfaces during adulthood. Now, it is very important that we understand that Shakespeare's Adonis is not much older than a young soul just stepping out of the chrysalis of adolescence into adulthood. Thus, in his case the first four stages (stages one, two, three, and four) would not be applicable at all. Again the last two stages (seven and eight) among the ones applicable to adulthood would be out of the purview of his age. The only two psycho-social developmental stages applicable to young Adonis would be the stage five of adolescence and stage six of very early adulthood.

According to Erik Erikson, the sixth stage of psychosocial development in adolescence pivots around the normative crisis of "identity versus role confusion" where the adolescent tries out various roles in order to settle upon an anchoring self-identity in a bid to "fit in"- the role of the good boy/girl, the rebel, the dutiful, the athlete, the adventurer, the supercool operator, and so on. At this stage the adolescent weighs what he is supposed to do against what he wants to do. He tries out myriad potential social selves-persons that they might potentially become, before zeroing in and settling upon a cognitive framework for understanding themselves and fixing up upon what psychoanalysts call a "self-schema".

Adonis, in his late adolescence and early adulthood, was in all probability going through the double trouble of the "fifth stage crisis" of "identity versus role confusion" and the "sixth stage crisis" of "Intimacy versus Isolation" as his personality was trying hard to figure out his own place in the social world as his Superego Identity began to form up, followed by a sense of sexual identity. He was trying his best to fix up a role for himself and the role that appeared most appealing to him was that of the fearless dashing hunter who never batted an eyelash before taking on fiercely ferocious brutes like a wild boar.

Under the sixth stage where the conflict is between Love and Intimacy versus Isolation, Adonis falters and teeters to find a footing. Rather than embracing Intimacy, Adonis seems to be sliding more towards Isolation. As stated earlier, Erikson suggests that Intimacy has a counterpart in what is known in Psychoanalytic parlance as Distantiation which connotes the readiness to isolate oneself from those, whose existence seems to choke one's own Dasein.

Venus tried coaxing Adonis into submission. Adonis, feeling threatened without even realizing it, promptly chose "Distantiation".

\section{The "Self-Schema"}

James Marcia, in his work, Ego Identity and Personality Disorders, takes the Eriksonian theory farther and argues that according to their coming to terms with their "self-schema", identity structurality in adolescents can be categorized into four groups (Marcia, 2007):

(1) Identity achievement which describes the determined ones who have already settled upon an identity;

(2) Identity moratorium, which would describe the plight of those who are still searching for an identity;

(3) Identity foreclosure which describes the state of people who have had their identities decided by someone else, viz. parents;

(4) Identity diffusion as the placid complacency of the ones who have not yet begun the process of identity formation.

Thinking along these lines, one realizes that Adonis's is a case hanging somewhere between identity achievement and identity foreclosure. Identity Achievement urged him to hunt boar-something that he had set his heart on, being drawn in this impressionable age to the macho adventurousness of boar hunting without a thought about the risks entailed. Rather the risk factor itself was probably what magnetized him with the 
ineluctable rush of adrenalin. Whatever it was that drew him to the sport, hunting boar was what Adonis, in the spree of adventure had zeroed in upon.

Yet Identity Foreclosure started choking him down when Venus attempted to decide for him that he should not go for hunting. Instead he should "settle" down in happy familiarity, fall in love, make love, and thus, help in the "increase" of Nature by edging his lineage forward. This threatened to take away from the young Adonis what he had just begun to cherish and relish as the new-found happiness of following his heart to the hunting sports he loved. He shrank back from Venus. He edged towards what Erikson had described as "Distantiation".

\section{Venus in the Subjective Role in Powerplay}

All that poor Adonis "wanted" to do in the long verse-story was to hunt boar. A Lacanian perspective at the issue would rake up suggestions of boar-hunting as "Objet petit a" or the "matheme" of desire for Adonis. Yet, what he was "supposed" to do in the rubric of the socio-cultural construct was constantly instructed to him by the older woman Venus who came increasingly to epitomize the very rationality and logicising that threatened to rob him of his freedom to follow his heart.

Venus here, then, played the rather dialectic role of mistress-mother to the adolescent Adonis. She kept wooing Adonis sensually like a mistress on the one hand and haranguing Adonis on the other, like a matriarchal agent from the grown up world of socio-psychological and behavioral norms, about the order of the world and how human beings ought to engage in lovemaking because it was almost a bounden duty of the microcosm to contribute to the "increase" of nature:

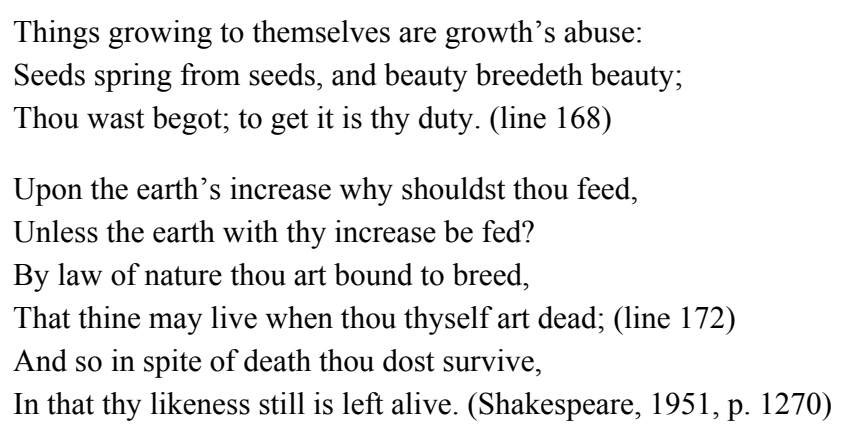

Thus, more than wooing Adonis and teaching him how to love, she goes on and on about why to love. And what she tells young Adonis by way of talking him into a conjugal relationship with herself could be ratiocinated through the lines of what Urie Bronfenbrenner calls the Ecological Systems Theory or the Bioecological model.

\section{Ecological Systems Theory}

Urie Bronfenbrenner (April 29, 1917-September 25, 2005), the Soviet Union-born American developmental psychologist, in his book The Ecology of Human Development: Experiments by Nature and Design formulated the idea of the Ecological Systems Theory, which later came to be known as the bioecological model. According to Bronfenbrenner, any social human being is a part of a layered system of the universe which he calls "Chronosystem" (Bronfenbrenner, 1979). The Chronosystem comprises of a number of other sub-systems that lay seminal roles in the formation of human personality as a socio-cultural being. 


\section{The Chronosystem}

As per this multi-tiered construct, there is the "microsystem" where people interact with their immediate surroundings where peers, siblings, and family play a large part. Next comes the "mesosystem" where the individual interacts with a circle which is a bit wider in that, it includes the home, workplace, neighborhood, and clan of the individual. Next comes the "exosystem", where interaction occurs indirectly, implying the remote connectivity to the surroundings of the mesosystem of those in the individual's own direct mesosystem. Environment plays a big part here. Lastly, there is the "macrosystem" where the individual acts as the miniscule component of the macro-universe, which in turn is governed and controlled by a panopticon of socio-political systems, religio-cultural values, beliefs, laws, and customs. Bronfenbrenner opines that a human being has his rights from, as well as responsibilities towards all these "systems" that he belongs to.

Bernice Neugarten takes Bronfenbrenner's theory a bit forward and says that inter-relation with each system has its own appointed time and age and thus runs according to a sort of internalized calendar which could be called "social age clock" (Neugarten, 1996). This suggests that human beings, being part of this vast macrosystem, have to maintain a sort of schedule of what should be done and when it should be done.

Now when Venus reasons it out with Adonis in a bid to make him realize his duty towards nature and society in joining the age-old natural tradition of procreation by giving in to the convention of love and reproduction, she actually fortifies what Bronfenbrenner tried to categorize into the Chronosystem Theory - that human beings are only part of a bigger macro-structure with their own part to play in maintaining the order and decorum of the socio-natural construct.

She denigrates the weltanshauung that advocates a selfish, solipsistic, subjective, and "narcissistic" existence as opposed to a more philanthropic and disciplined existence:

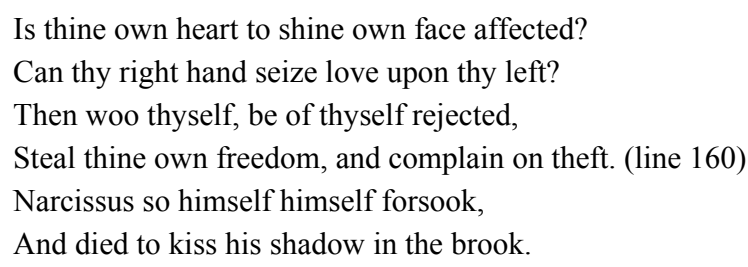

She tries her best to bring the stubborn Adonis round to the fact that man cannot live for himself alone. Being a part of the vast macrosystem, man has to follow cosmic norms of life and generation and generativity. She tries a thousand and one arguments to clinch her point of an idealistic ontology, punctuated by the specific decorum of duty.

Torches are made to light, jewels to wear,

Dainties to taste, fresh beauty for the use, (line 164)

Herbs for their smell, and sappy plants to bear;

And so are humans made to procreate and keep the natural order of live going great. (Shakespeare, 1951, p. 1270)

Venus, apparently like a coquettish, frenzied lover, uses her argument ostensibly to persuade Adonis into lovemaking. Yet, subcutaneously she champions the efficacy of the layered social existence that Elizabethans set such great store by. Years later, Bronfenbrenner would describe through his Ecological Systems Theory. Again, when she exhorts Adonis: "Make use of time, let not advantage slip" (line 129), she may as well have been talking about Neugarten's social age clock, too. 


\section{Queer Theoretical Angle}

Again, scrutinizing this long poem from the angle of Queer Theory, one could discern quite an insolent tangent of suggestivity. The Elizabethan times was notoriously infamous for what had come to be known as "buggery with beasts" - an unnatural sexual intimacy with animals, not unlike sodomy, that came to be declared as a crime punishable by death penalty in 1534. The young and nubile Adonis's surprisingly mystifying disregard of and annoyance at the overtly erotic advances of the breathtakingly beautiful Venus could imply a daringly inquisitive angle of observation that could bring up the rather unnerving suggestion that young Adonis was more interested in "boar" that was in woman, as would be naturally expected of him. Anthony Mortimer too, feels that Shakespeare could have been insinuating gingerly towards an alternate sexuality in Venus and Adonis through a tentative edging towards the idea of "buggery withe beasts" (Mortimer, 2000). However, a lot more thought, evidence, and rationalizing would have to be spared on establishing this rather sensitive angle in Shakespeare's Venus and Adonis, which was better left unexplored in this dissertation which aimed more at a psychoanalytical stance on Venus and Adonis than anything else.

\section{Conclusion}

Thus, to round off the dissertation, I would like to wonder what exactly the tongue-in-cheek 25 year-old William Shakespeare was trying to do through this rather stunner of a Renaissance work. But one thing is for sure, Venus and Adonis as a poem may have been the underdog as far as critical reception was concerned, but it has food for thought enough to make an intriguing case study per se. William Shakespeare has always been one of the most adorable literary mavericks that English literature has ever produced. Most of the oeuvre of his writing - be it drama or his sonnets or long poems, Shakespeare has forever had his own way, thereby creating a unique order of his own. And Venus and Adonis is no exception either.

\section{References}

Bronfenbrenner, U. (1979). The ecology of human development: Experiments by nature and design (pp. 64, 76). Cambridge, MA: Harvard University Press.

Erikson, E. H. (1950). Childhood and society (pp. 50-52). New York: W. W. Norton and Company, Inc..

Marcia, J. E. (2007). Ego identity and personality disorders. Journal of Personality Disorders, I, 527.

Mortimer, A. (2000). Variable passions: A reading of Shakespeare's "Venus and Adonis". New York: AMS Press.

Neugarten, B. L. (1996). The meanings of age: Selected papers of Bernice L. Neugarten. Chicago: The University of Chicago Press.

Shakespeare, W. (1951). Complete works. P. Alexander (Ed.). Great Britain: The English language Book Society and Collins.

\section{Appendix: About the Author}

Dr. Aparajita Hazra is an Associate Professor and Head of the Department of English, SKB University, West Bengal, India. As a gold medallist and a National Scholar, she has contributed over 60 articles on literary topics in various national and international journals and newspapers, too.

She has also presented numerous papers in various national and international seminars in India and abroad in countries like France Macau, Malaysia, and Scotland. She has been invited as guest faculty in educational programmes on television. She has also been invited to deliver lectures on literature in various universities and Academic Staff Colleges in India.

She is the Indian collaborator of the World Shakespeare Project, a global venture initiated by Emory University, Atlanta. She also takes classes regularly with the students of Emory University through video-conferencing. 
She has four books to her credit—The Terrible Beauty, Her Hideous Progeny: Mary Shelley's Frankenstein, The Brontes: A Sorority of Passion, and The Art of Articulation from Macmillan Publishers. A fifth book on the Supernaturalism in Films and Literature is in the offing from Beewulf Press, Denmark.

She has also adapted Shakespeare's Macbeth into a local dialect called "Manbhum" as a project for Performative Shakespeare. Her team won the second place in a contest for local adaptations of classical texts. 